\title{
Key Performance Indicator Assessment Information System (KPI) Faculty of Engineering Using Website-Based AHP Method
}

\author{
Dedy Rahman Prehanto* \\ Informatics Engineering Department, of Engineering Faculty, Surabaya State University \\ Surabaya, Indonesia \\ dedyrahman@unesa.ac.id \\ Bambang Sujatmiko \\ Informatics Engineering Department, of Engineering Faculty, Surabaya State University \\ Surabaya, Indonesia \\ bambangsujatmiko@unesa.ac.id
}

The research is financed by Asian Development Bank. No. 2006-A171(Sponsoring information)

\begin{abstract}
The main performance indicators (KPI) are ministerial performance targets imposed by the ministry of education on all universities under its auspices. The state university of Surabaya to realize the main performance indicators (KPI) from the ministry divided the performance with 7 faculties. The Faculty of Engineering is one of the 7 faculties that have been targeted by UNESA. The decision-making process from the various alternatives that exist requires the existence of a criterion. One of the methods used in this research is the Analytical Hierarchy Process (AHP) method. Aspects of performance appraisal that will be used as criteria include the following: Performance Assessment Based on the increasing quality of higher education graduates, Increasing the quality of higher education lecturers, Increasing the quality of curriculum and learning, Improved governance of work units within the Directorate General of Higher Education. From some of these weaknesses in monitoring and realizing the main performance indicators of the university, it is necessary to make software to make it easier for the dean to monitor performance. The software serves to monitor the main performance indicators of the engineering faculty by the dean. Based on these problems, it is necessary to conduct a research entitled Information System Assessment of Key Performance Indicators (KPI) of the Faculty of Engineering Using the Website-Based AHP Method.
\end{abstract}

Keywords: SPK AHP, website php, mysql

DOI: $10.7176 / \mathrm{IKM} / 12-2-02$

Publication date: February $28^{\text {th }} 2022$

\section{Introduction}

Key performance indicators (KPI) are service delivery targets imposed by the training service on all tertiary institutions under its protection. Surabaya public universities understand the main performance indicators (IKU) from the department of isolating exhibitions with 7 sources. The design staff was one of the 7 resource persons who received Unesa's goals. To achieve this goal, personnel separate the focus of implementation from offices and study programs. In order to understand the instructions of this exhibition, every time it is done physically, the administrative staff will think that it is difficult to filter the procurement of focuses that have been isolated to majors and study programs. With the manual framework, you need to examine the majors and courses individually by calling and recap individually the focus of achievement for the office and course of study.

From here, the workforce initiative will set aside a lengthy effort to screen execution. To avoid non-targeted evaluation when selecting the best workers, it is important to have techniques that can assist and work with the organization in making decisions. In data innovation, dynamic framework is the part of science that lies between data framework and smart framework. The dynamic cycle of the various options that exist requires a standard. Each action should have an option to answer the important question of how well the option can address a nearby problem.

Many strategies can be used in a dynamic framework. One of the strategies used in this test is the Analytical Hierarchy Process (AHP) technique. The idea of the AHP strategy is to change subjective qualities into quantitative qualities. The specialist explained that one of the options for avoiding non-targeted evaluations in the evaluation, using the part of the worker performance exam to be used as a rule includes the accompanying: Performance Assessment Depending on the nature of the continuing education graduate developing, Expanding the nature of further education speakers, Expanding the nature of the educational program and learning, Improvement administration of work units within the Directorate General of Advanced Education.

\section{Method}

2.1 Analytic Hierarchy Process (AHP)

AHP is a far-reaching philosophy, which provides the capacity to dynamically combine quantitative and subjective 
variables for people and encounters (T.L. Saaty, L.G. Vargas, 2012). This model was created by Thomas L. Saaty, a mathematician at the College of Pittsburgh, USA. This model can help human temperament because it includes human wisdom as subjective information. The human insights included here are the views of (specialists), especially individuals who really understand the problem presented, feel the results of a problem, or have an interest in the problem (E. Nurmianto and N. Siswanto, 2016).

Basically AHP is a strategy for tackling a complex and unstructured problem into its segments, organizing these parts in a progressive system, incorporating numerical qualities in place of human insight in performing relative checks, lastly providing a combination that decides the demand and value requirements of the segment. this (TL Saaty, LG Vargas, 2012). AHP was introduced as a progressive model consisting of goals, standards, perhaps several degrees of sub-measurements and options for each option.

AHP is an organized strategy identified by dynamic interaction on complex issues, which consists of many options such as activities, activities, and situations. AHP is made with a progressive construction of several dynamically elective mixtures. For example information, experience and instinct. Furthermore, this strategy gives everyone the opportunity to make choices about various types of problems. For example, electronic waste management (D. Rimantho, B. Cahyadi, D. Dermawan, 2015), applies the AHP strategy to choose natural materials investigation techniques (D. Rimantho, M. Rachel, B. Cahyadi, 2016), as a tool for determine choices about the avoidance of work accidents for wasted authority workers (D. Rimantho, B. Cahyadi., 2016), which are used to make a progressive construction of the problem of need for hardware alignment in the drug business (D. Rimantho, TA Rahman, B. . Cahyadi., 2017).

AHP is a powerful strategy for dynamics when there is subjectivity in an issue (T. Semih and S. Seyhan., 2011). In addition, AHP is appropriate for dealing with problems where the choice actions are orchestrated in sequence into sub-models. Utilizing the development of pairwise correlation of components of a direct pecking order can reduce complex choices.

\section{Research methods}

The research method used to produce a product and test the product so that it is effective and ready for use by the user (Sugiono, 2009). The flow of this research is presented in Figure 1.

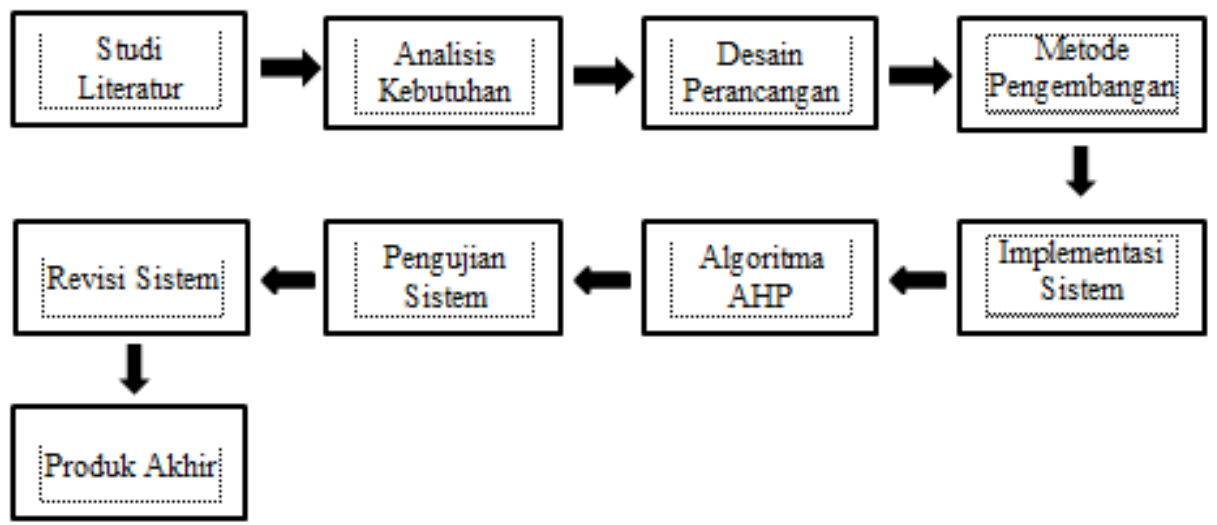

A. System Requirements Analysis

Figure 1 Research Flow

1. Functional Needs

a. The system can manage data

b. The system can manage data

c. The system can calculate the weight value of each system criterion and assign each value according to

the Analytical Hierarchy Process method

d. The system can determine and display the results of the Analytical Hierarchy Process method

2. Non-Functional Needs

a. Operating system using a minimum of windows 7

b. Hard disk capacity of at least $80 \mathrm{~GB}$

c. The programming language uses php and the database uses mysql.

$\mathrm{d}$. The system has an interface design that is easy to use by users and a responsive display.

B. Design Design

1. Data Flow Diagrams (DFD) (Figure 2)
2. Desain flowchart (Figure 3) 


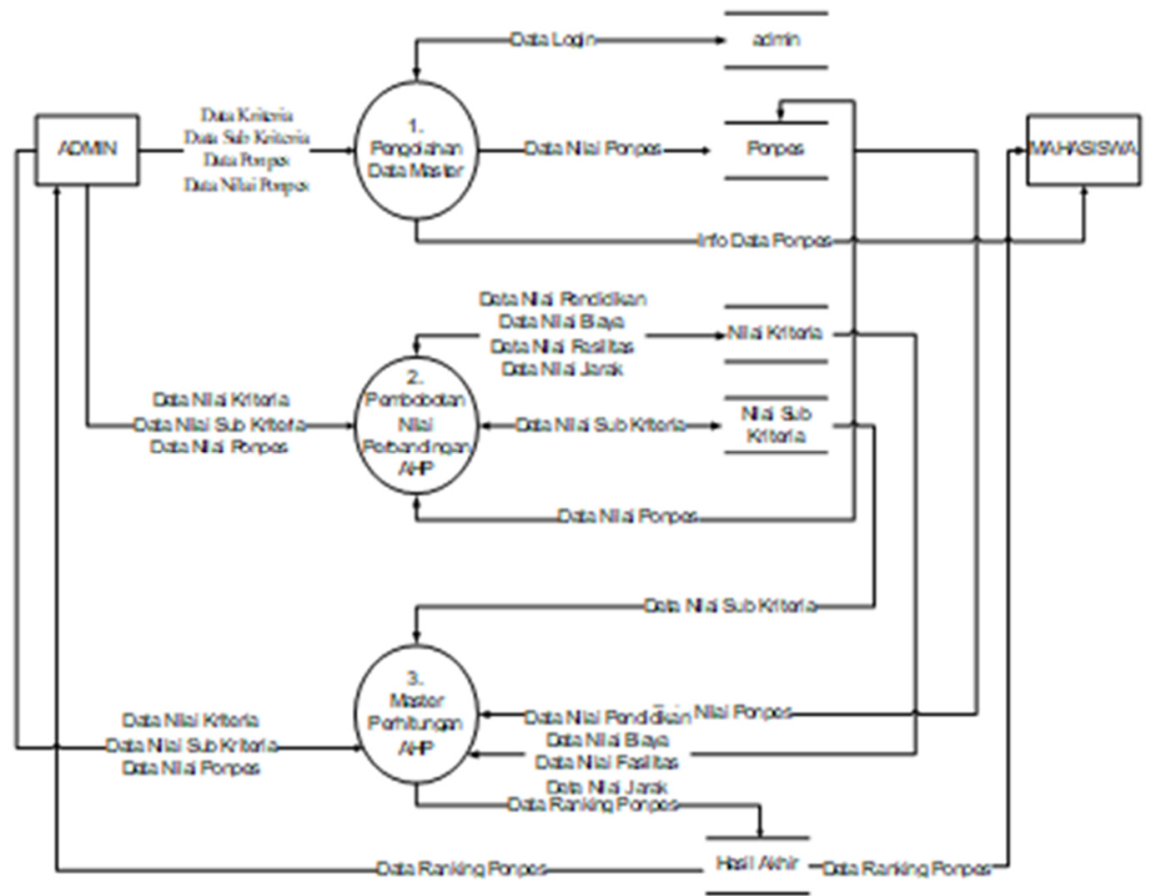

Figure 2 DFD

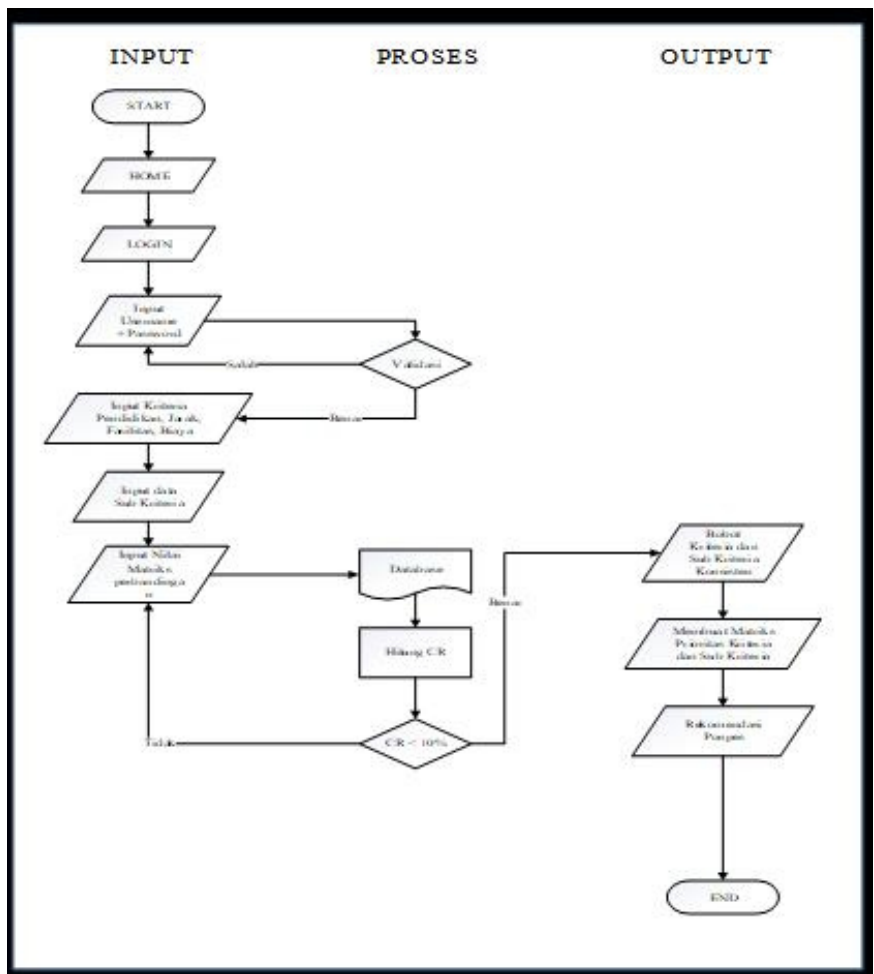

Figure 3 Flowchart System

\section{Results and Discussion}

Implementation of an information system for assessing key performance indicators by applying the website-based AHP method. Aspects of performance appraisal that will be used as criteria include the following: Performance Assessment Based on the increasing quality of higher education graduates, Increasing the quality of higher education lecturers, Increasing the quality of curriculum and learning, Improved governance of work units within the Directorate General of Higher Education. This information system serves to monitor the main performance indicators of the engineering faculty by the dean. At the beginning of this information system is run will display the login page. On the login page there is a username and password that must be filled in first. Here, if the username 
and password are entered incorrectly or incorrectly, the system will notify you if there is an error and cannot enter the dashboard page. The login page display can be seen in Figure.

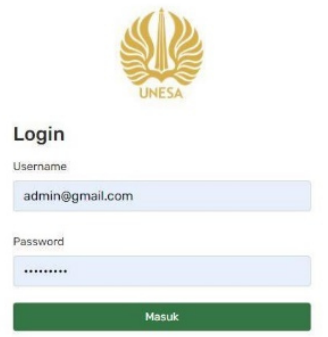

Figure 3 Flowchart System

If the username and password entered on the login page are correct, the system will continue the process and display the dashboard page as shown in Figure 4. On the dashboard page there is a menu for managing data for vice dean 1, academics, managing data for vice dean 2, general finance, managing data for deputy dean 3 , and student affairs.

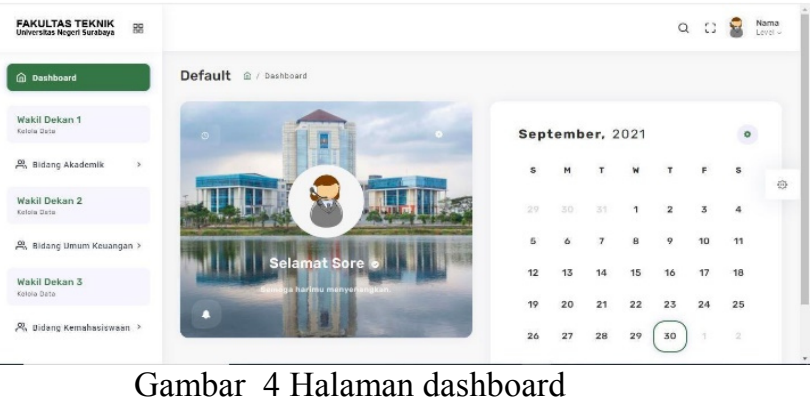

On the academic field menu, there is a choice of performance agreement and performance agreement indicators. The performance agreement menu will display activity targets, activity performance indicators, and the number of faculty targets that will be displayed per each study program as shown in Figure 5.

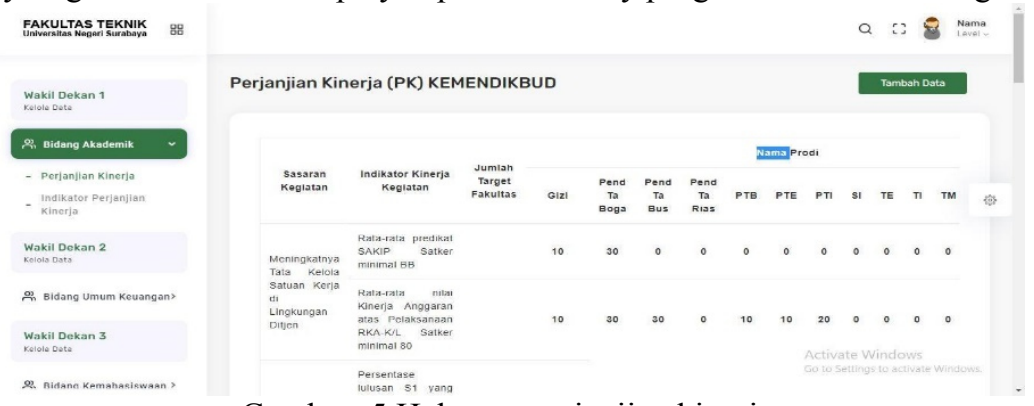

Gambar 5 Halaman perjanjian kinerja

On the other Vice Dean 1 menu, there is a performance agreement indicator menu that can provide information related to activity targets, activity performance indicators, number of faculty targets, and unit information. The display of the performance indicator menu can be seen in Figure 6 .

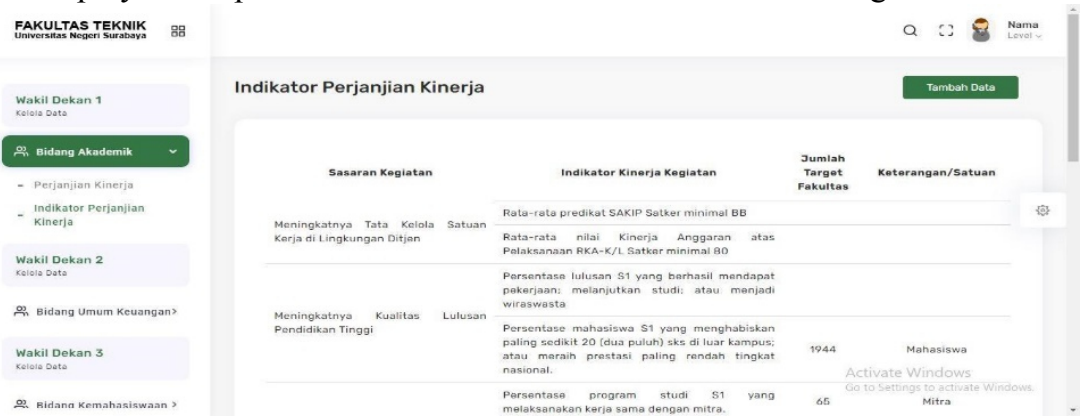

Gambar 6 Halaman indikator perjanjian kinerja

In the menu for the vice dean 2 there is a menu of FT assets, sources of funds, use of funds, organizational 
structure, performance indicators \& faculty targets, and performance accountability. The FT asset page contains information on the number of students, the number of academic staff, the number of educational staff, and infrastructure. In addition to the information presented, there is also a button to add data, which can be seen in Figure 7.
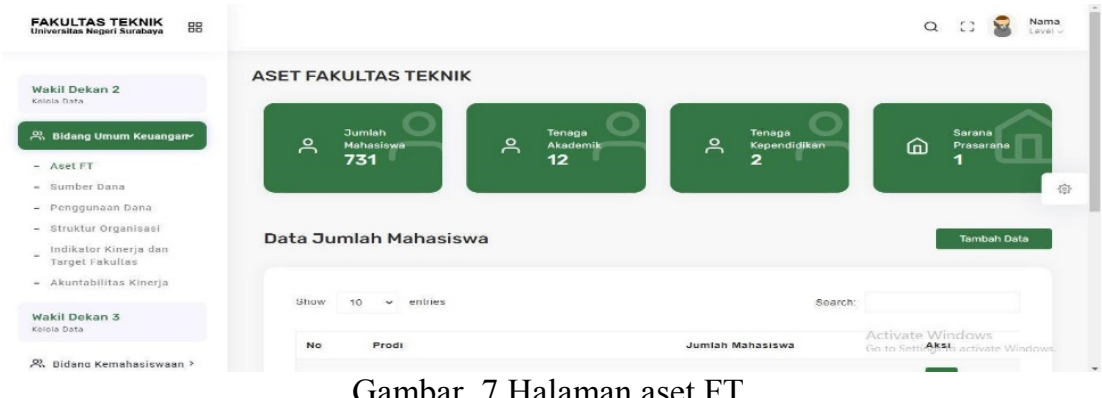

On the source of funds page there is information on the source of funds, the initial allocation, and also the final allocation which is equipped with an add data button. In addition to adding data to add new sources of funds, there is also an edit button for any information on existing sources of funds, which can be seen in Figure 8.

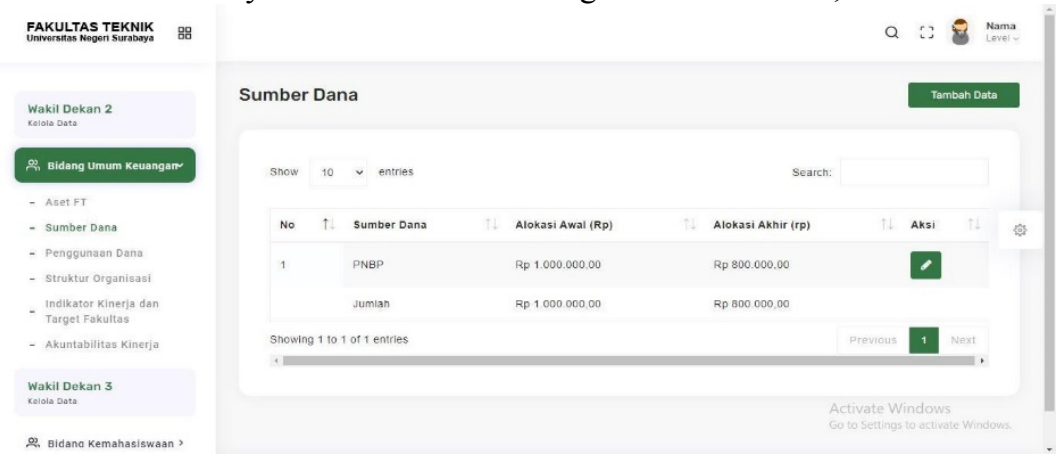

Gambar 8 Halaman sumber dana

On the budget realization page there is information on output, allocation, and also the percentage of realization that is equipped with an add data button. In addition to adding data to add budget realization, there is also an edit button for any existing realization information, which can be seen in Figure 9.
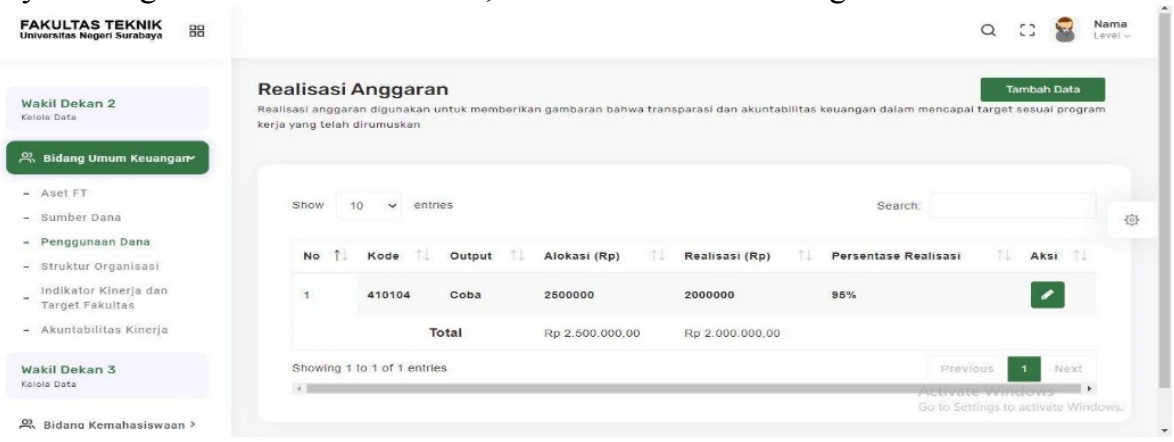

Gambar 9 Halaman realisasi anggaran

On the performance indicators and faculty targets page, there are program targets, numbers, performance indicators, targets, and achievements that are equipped with an add data button. In addition to adding data to add new program goals, there is also an edit button for each existing faculty target and performance indicator information, which can be seen in Figure 10.

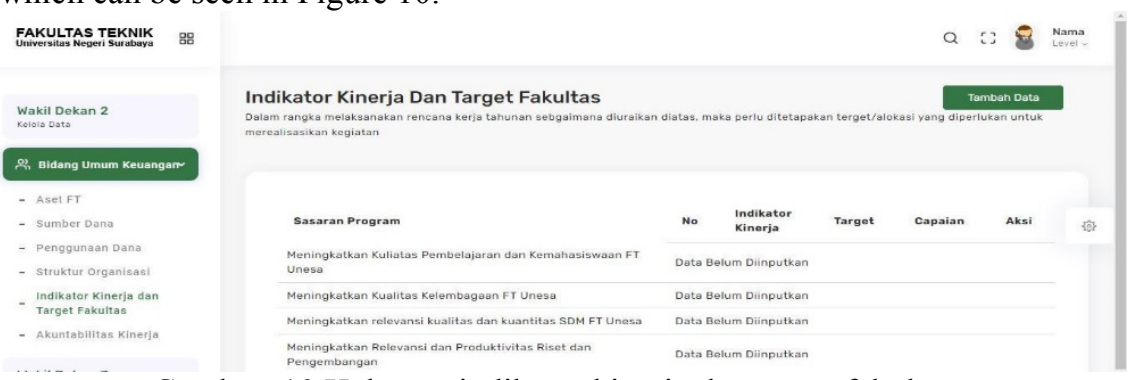

Gambar 10 Halaman indikator kinerja dan target fakultas

On the performance accountability page, there are program targets, numbers, performance indicators, targets, 
and achievements that are equipped with an add data button. In addition to adding data to add new program goals, there is also an edit button for any existing performance accountability information, which can be seen in Figure 11.

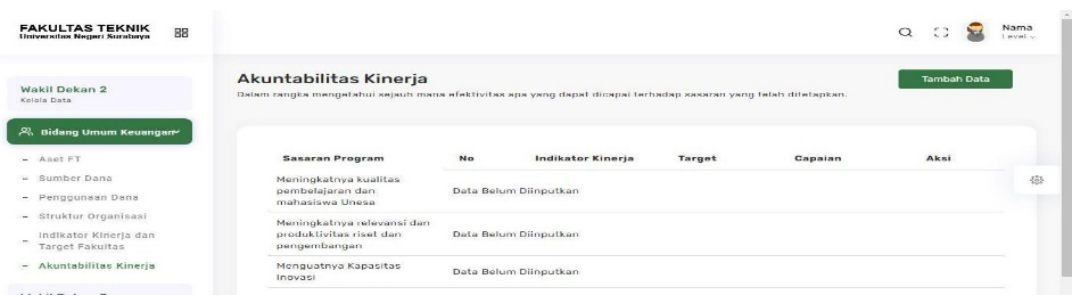

Gambar 11 Halaman akuntabilitas kinerja

On the recognition page there are program targets, numbers, performance indicators, targets, and achievements that are equipped with an add data button. In addition to adding data to add new program goals, there is also an edit button for any existing performance accountability information, which can be seen in Figure 11.
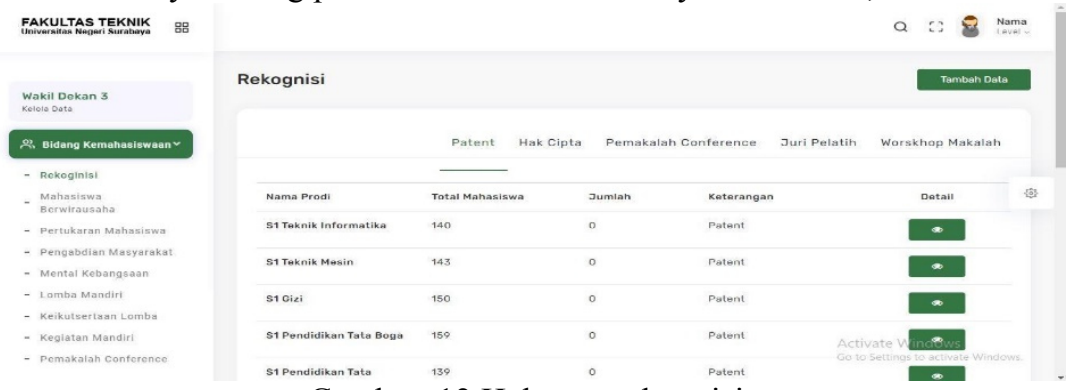

Gambar 12 Halaman rekognisi

On the entrepreneurship student page, there are entrepreneurship seminars, PMW coaching, Entrepreneurial Assistance, and entrepreneurship expos which are equipped with the add data button. The display is presented by displaying the name of the study program, total students, number, and description. In addition to adding data to add new program goals, there is also an edit button for any existing performance accountability information, which can be seen in Figure 13.

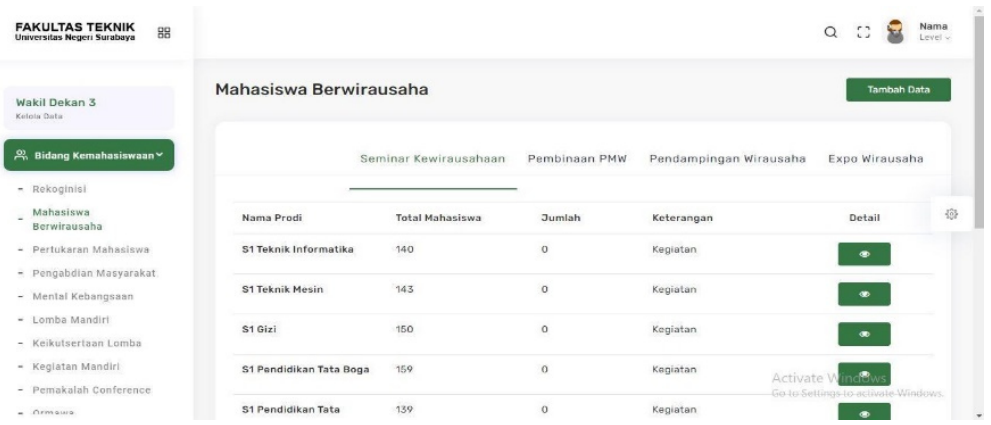

Gambar 13 Halaman Mahasiswa Berwirausaha

On the student exchange page there are international and national categories which are equipped with an add data button. The display is presented by displaying the name of the study program, total students, number, and description. In addition to adding data to add new data, there is also a button to view any existing student exchange data information, which can be seen in Figure 14.

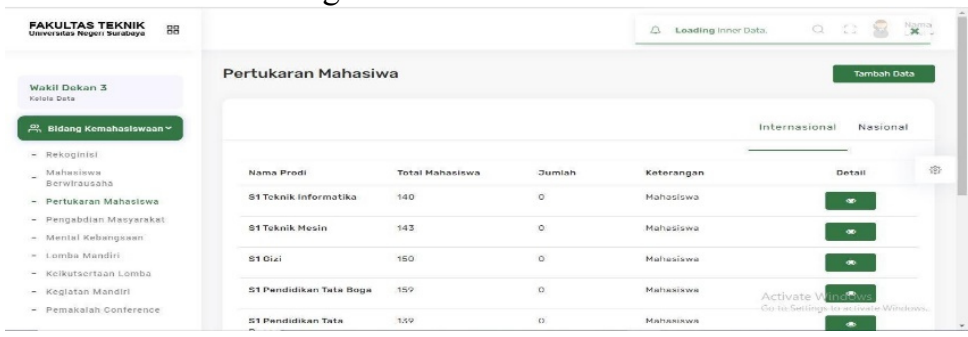

Gambar 14 Pertukaran Mahasiswa

On the community service page there is the name of the study program, the total number of students, and a description that is equipped with the add data button. In addition to adding data to add community service, there is also an edit button for any existing community service information, which can be seen in Figure 15. 


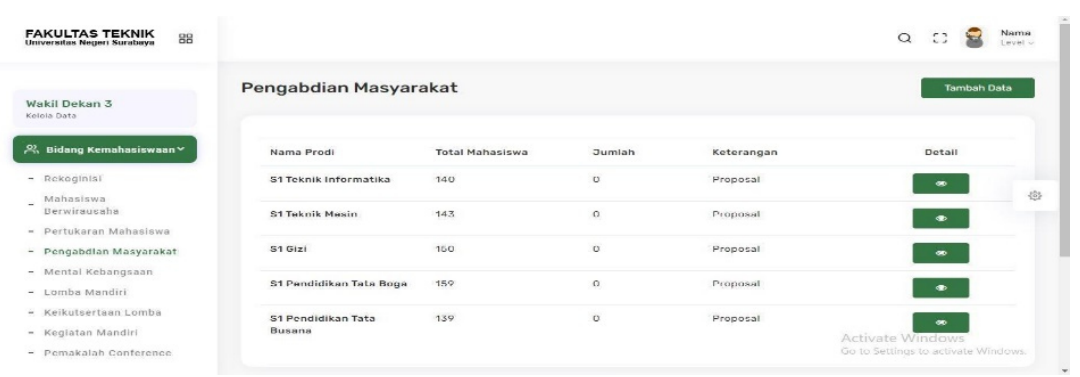

Gambar 15 Halaman pengabdian masyarakat

On the national mental page, there is an entry to complete the national mental data which contains the person in charge of the activity by choosing an action. In addition to adding data to add national mental data, there is also an edit button for any available information, which can be seen in Figure 16.

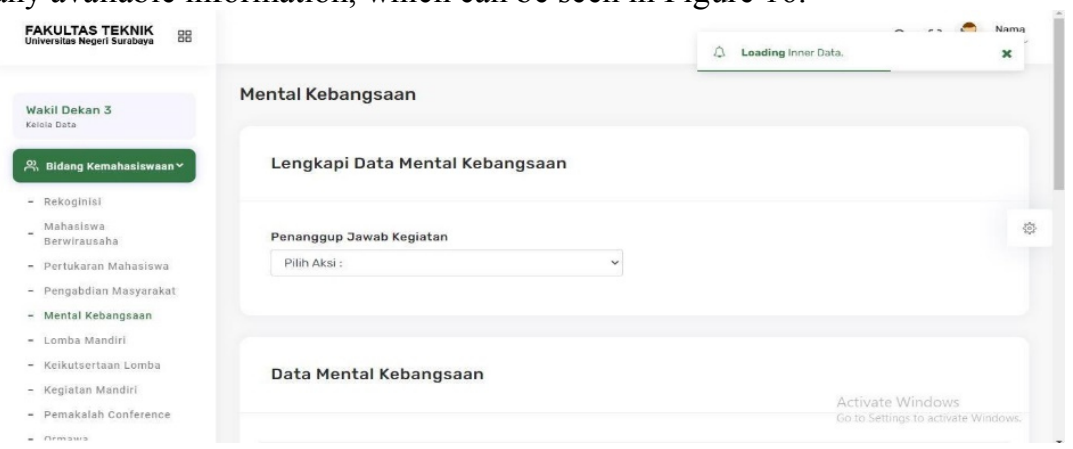

Gambar 16 Halaman mental kebangsaan

On the independent competition page there is an entry to complete the independent competition data which contains the organizer, number of activities, and information by selecting add. In addition to adding data to add independent race data, there is also a button to view the data that has been added. And there is information on the target of existing competitions, which can be seen in Figure 17.

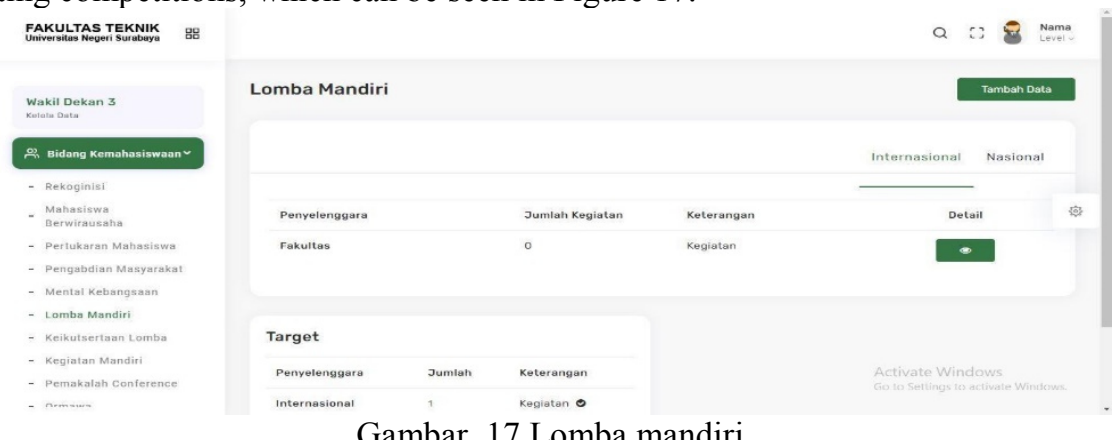

Gambar 17 Lomba mandiri

On the Competition Participation page, there are entries to complete the data for the talent interest competition, Pilmapres, KDMI, NUDC, KMHE, creativity, PKM, robots, GEMASTIK, each of which contains the name of the study program, total students, number, and information by selecting add. In addition to adding data to add race data, there is also a button to view the data that has been added. And there is information on the target of existing competitions, which can be seen in Figure 18.
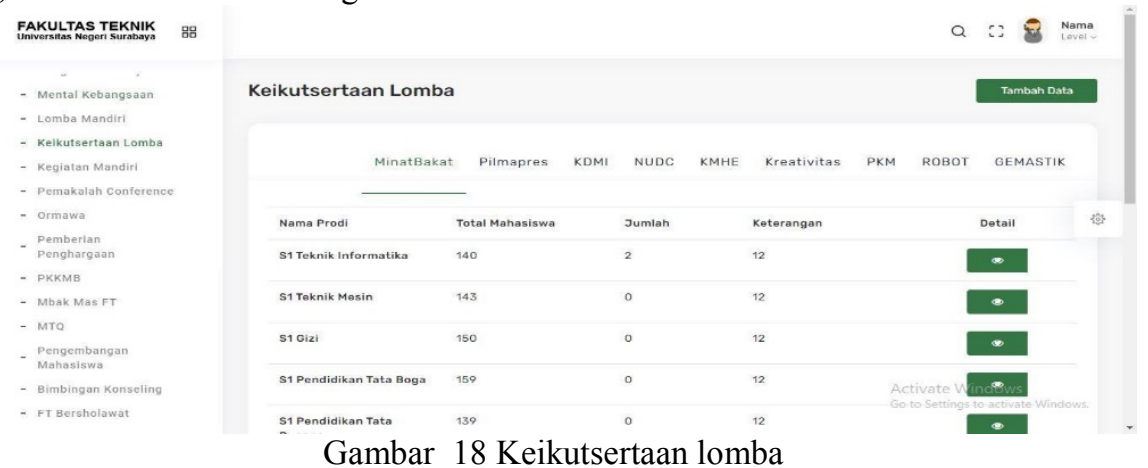

On the participation page as a speaker in the conference there are international and national options to complete the data containing the name of the study program, total students, number, and information by selecting 
add. In addition to adding data to add data, there is also a button to view data that has been added which can be seen in Figure 17.

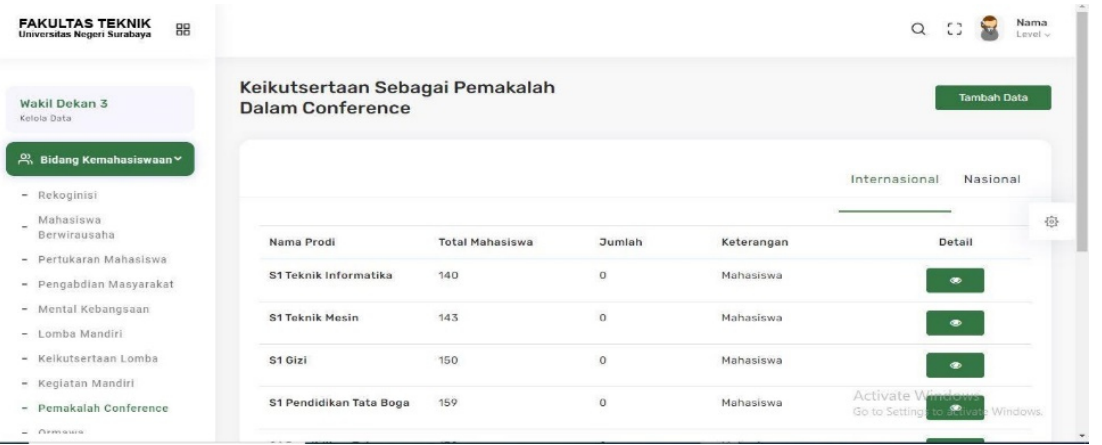

Gambar 19 Halaman keikutsertaan sebagai pemakalah dalam conference

On the Student Development page there are fields to complete the data for the name of the study program, total students, number, and information by selecting add. In addition to adding data to add student development data, there is also a button to view the data that has been added which can be seen in Figure 19.

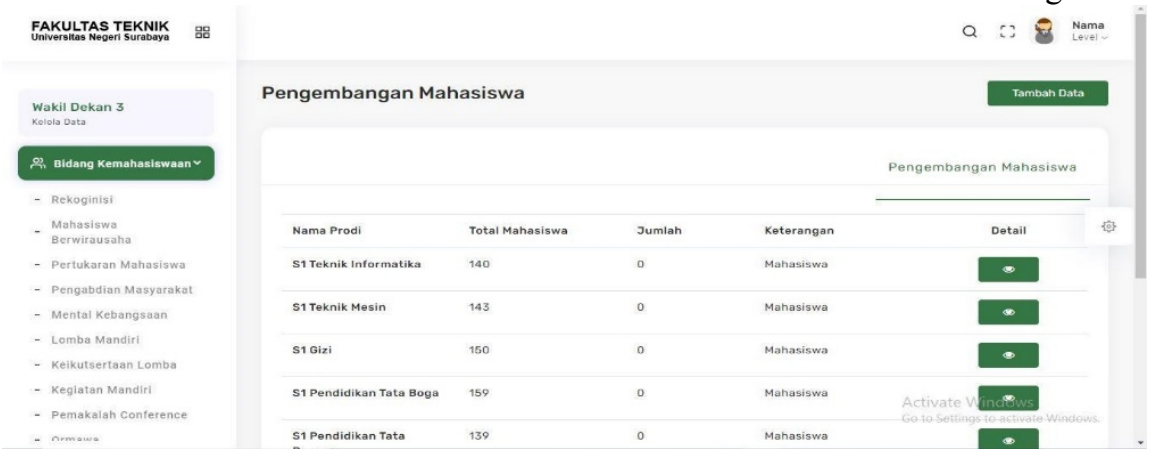

Gambar 20 Halaman Pengembangan Mahasiswa

\section{Conclusion}

The creation of an information system for assessing the main performance indicators of this website-based early childhood learning application will assist the engineering faculty in assessing performance. With the AHP method, it directly assists in the processing of the main performance assessment. Based on the results of the tests carried out, it can be seen if the application built can run as desired. For further development some new or additional features can be added

\section{References}

Artika, Rini. 2013. Penerapan Analitycal Hierarcy Proccess (AHP) dalam Pendukung Keputusan Penilaian Kinerja Guru Pada SD Negeri 095224. ISSN : 2301-9425

D. Rimantho, B. Cahyadi, D. Dermawan. "Application analytic hierarchy process (AHP) by utilizing the Expert Choice as a tool in decision-making: a case study of e-waste management in Surabaya, Indonesia." In Conference Proceedings 8th International Seminar on Industrial Engineering and Management, Malang, Jawa Timur, 2015.

D. Rimantho, M. Rachel, B. Cahyadi, Y. Kurniawan. "Aplikasi Analytical Hierarchy Process Pada Pemilihan Metode Analisis Zat Organik Dalam Air.” Jurnal Ilmiah Teknik Industri, Vol. 15(1), pp. 47-56, 2016, https://doi.org/10.23917/jiti.v15i1.1603.

D. Rimantho, B. Cahyadi. "Six Sigma Method Approach in the Prevention of Occupational Accidents on the Solid Waste Collector in South Jakarta." ARPN Journal of Engineering and Applied Sciences, Vol. 11(16), pp. 10014-22, 2016.

D. Rimantho, T.A. Rahman, B. Cahyadi. "Application of six sigma and AHP in analysis of variable lead time calibration process instrumentation." In AIP Conference Proceedings, Vol. 1813(1), 040004, 2017, http://dx.doi.org/10.1063/1.4975969.

E. Nurmianto dan N. Siswanto. "Perancangan Penilaian Kinerja Karyawan berdasarkan Kompetensi Spencer dengan Metode AHP.” Jurnal Teknik Industri, Vol. 8(1), pp. 40-53, 2006. Kusrini. 2007. Konsepdan Aplikasi Sistem Pendukung Keputusan. Yogyakarta : C.V Andi Offset.

Seafudin, dan Wahyuningsih, Sri. 2014. Sistem Pendukung Keputusan Untuk Penilaian Kinerja Pegawai Menggunakan Metode Analitical Hierarchy Process (Ahp) pada RSUD Serang. ISSN: 2406-7768

Septian, Dian dan Siahaan, Fernando B. 2017. Sistem Penunjang Keputusan Pemilihan Karyawan Berprestasi 
Dengan Metode Analitical Hierarchy Process (AHP) pada PT. Ichiya Indonesia. ISSN: 2442- 2436

T. Semih dan S. Seyhan. "A multi-criteria factor evaluation model for gas station site selection." Journal of Global Management. Vol. 2(1), pp. 12-21, 2011. T.L. Saaty dan L.G. Vargas. Models, Methods,Concepts and Applications of the Analytic Hierarchy Process (Second Edition). New York: Springer, 2012. 